\title{
Treatment of Wastewater Containing a Mixture of Heavy Metal lons (Copper-Zinc, Copper-Nickel) using Ion-Exchange Methods
}

\author{
Anastasiia Koliehova ${ }^{1 *}$, Hanna Trokhymenko ${ }^{1}$, Melnychuk Svitlana' ${ }^{1}$, Mykola Gomelya ${ }^{2}$ \\ 1 Admiral Makarov National University of Shipbuilding, 54024, Heroiv Ukrainy av. 9, Mykolaiv, Ukraine \\ 2 Igor Sikorsky Kyiv Polytechnic Institute, 03056, Peremogy av. 37, Kyiv, Ukraine \\ * Corresponding author's e-mail: nastya.sukhareva92@gmail.com
}

\begin{abstract}
The main aim of the scientific research was to study the ion-exchange processes in the treatment of industrial wastewaters containing a high concentration of heavy metal ions $\left(\mathrm{Cu}^{2+}, \mathrm{Zn}^{2+}, \mathrm{Ni}^{2+}\right)$. The sorption results of heavy metal mixtures $(\mathrm{Cu}-\mathrm{Zn}, \mathrm{Cu}-\mathrm{Ni})$ from model solutions of sulfate salts on a strong-acid $\mathrm{KU}-2-8$ cation exchanger in the $\mathrm{H}^{+}$-form were presented. The metals concentration was $10-50 \mathrm{meq} / \mathrm{dm}^{3}$. The efficiency conditions of cation regeneration in $\mathrm{Cu}^{2+}-\mathrm{Zn}^{2+}, \mathrm{Cu}^{2+}-\mathrm{Ni}^{2+}$-forms by 5,8 and $10 \%$ sulfuric acid solutions were studied. It was shown that the heavy metals from aqueous media can be removed not only from ion exchangers, but can also be restored from regenerative solutions by electrolysis to obtain metals in pure form. In general, the research results showed that the use of ion exchange is very effective in removing the heavy metal ions. The sorption efficiency and regeneration efficiency was about $100 \%$.
\end{abstract}

Keywords: heavy metals, ion exchange, regeneration, cation exchanger, sorption.

\section{INTRODUCTION}

Heavy metals are some of the most dangerous pollutants in the hydrosphere, which are formed during the human activity process. Infiltrating into reservoirs, they can be accumulated in living organisms and form toxic compounds, while migrating in the ecosystem through supply chains. The level of heavy metal pollution has increased sharply for the last 50 years as a result of the exponential increase in the application of heavy metals in industrial processes [Pawan 2012].

The main sources of contributing to the release of heavy metals into the environment are non-ferrous metallurgy, day and varnish industries, machine industry, galvanic production, battery and glass manufacturing, plants chemical processing, phosphorus fertilizers, etc [Dolina 2008.]. The industrial sewage is polluted with heavy metal salts, acids and alkalis, formed during processing and details washing [Carstea et al. 2016]. Therefore, removal of heavy metal ions from industrial waste through treatment is very relevant for Ukraine and other countries in the world. This issue can be solved by introducing low-cost technologies for extracting valuable metals from industrial wastewater [Koliehova et al. 2018].

There are many methods for extracting heavy metals from sewage, but they all have both advantages and disadvantages [Femina Carolin et al. 2017; Gunatilake 2015; Azimi et al. 2017].

The most prospective methods for extracting heavy metal ions from sewage of different sources are ion exchange [Malovanyy et al. 2019] and electrolysis which allow organizing closed (nonstop) water-use cycles and provide creation of low-waste processes for the processing of waste regenerative solutions [Verbych et al. 2005].

In the following works [Trokhymenko et al. 2017], the authors studied the ion exchange properties of cation exchangers, showed high sorption and desorption efficiency of heavy metals from solutions.

The following paper [Markov et al. 2010] shows that strong-acid KU-2-8 cation 
exchanger has a high sorption rate of copper ions and is effective for purification of industrial effluents to the level of permissible concentrations of the discharges.

Therefore, strong-acid KU-2-8 cation exchanger in the $\mathrm{H}^{+}$-form with highly selective characteristics for heavy metal cations and resistant to acid and alkaline media was selected for the study on the sorption and desorption of heavy metals.

\section{MATERIAL AND METHODS}

This work is devoted to studying the processes of the simultaneous removal of $\mathrm{Cu}^{2+}-\mathrm{Zn}^{2+}$ and $\mathrm{Cu}^{2+}-\mathrm{Ni}^{2+}$ ions from the washing waters of galvanic plants by means of ion exchange under dynamic conditions.

The ion-exchange processes constituting the object of the research were model solutions of highly mineralized sewage containing heavy metal ions. The strong-acid KU-2-8 cation exchanger was used in the $\mathrm{H}^{+}$-form to study the sorption and desorption processes. The ion exchanger of $20 \mathrm{~cm}^{3}$ volume was placed in a burette (Fig. 1) with $2 \mathrm{~cm}$ diameter. The solution consumption during the sorption was $10-15 \mathrm{~cm}^{3} / \mathrm{min}$ and the regeneration $-2-5 \mathrm{~cm}^{3} / \mathrm{min}$.

As model solutions, mixtures of copper sulfate, zinc sulfate and nickel sulfate were dissolved in distilled water. The sorption and desorption were carried out with a mixture of two metal ions: $\mathrm{Cu}^{2+}-\mathrm{Zn}^{2+}-10,20,50 \mathrm{meq} / \mathrm{dm}^{3}$ and $\mathrm{Cu}^{2+}-\mathrm{Ni}^{2+}-10,20,50 \mathrm{meq} / \mathrm{dm}^{3}$. The $100-500 \mathrm{~cm}^{3}$ volume samples were selected during the sorption and analyzed for copper content with the spectrophotometry method [Lure 1989], for zinc and nickel with the trilonometry method, considering the copper concentration [Lure 1989]. In addition, the $\mathrm{pH}$ and acidity were monitored in the solutions.

The exchange of the ions during the sorption which occurred on the ion exchange resin can be described by the equation:

$$
\begin{gathered}
2 \mathrm{RH}+\mathrm{Cu}^{2+} \leftrightarrow \mathrm{R}_{2} \mathrm{Cu}+2 \mathrm{H}^{+} \\
2 \mathrm{RH}+\mathrm{Zn}^{2+} \leftrightarrow \mathrm{R}_{2} \mathrm{Zn}+2 \mathrm{H}^{+} \\
2 \mathrm{RH}+\mathrm{Ni}^{2+} \leftrightarrow \mathrm{R}_{2} \mathrm{Ni}+2 \mathrm{H}^{+}
\end{gathered}
$$

where: $R$ is the ion exchanger matrix; $\mathrm{Cu}^{2+}, \mathrm{Zn}^{2+}, \mathrm{Ni}^{2+}$ correspond to the heavy metal ions in the model solutions.
The total exchange dynamic capacitance of the sorbed metals was calculated according to the formula, $\mathrm{meq} / \mathrm{dm}^{3}$ :

$$
T E D C=\sum_{i=1}^{n} \frac{\left(C_{\text {initial }}-\mathrm{C}_{i}\right) \cdot V_{s}}{V_{i}}
$$

where: $C_{\text {initial }}$ is the initial metal ions concentration in the solution, meq $/ \mathrm{dm}^{3}$;

$C_{i}$ is the metal ions concentration in the i-th sample, $\mathrm{meq} / \mathrm{dm}^{3}$;

$V$ is the volume of sample, $\mathrm{cm}^{3}$;

$V_{i}^{s}$ is the volume of cationite, $\mathrm{cm}^{3}$;

$n$ is the number of samples taken.

Regeneration of the ionite exchanger was carried out by 5,8 and $10 \%$ sulfuric acid in the ion exchange column (Fig. 1). The sample volume amounted to $20-50 \mathrm{~cm}^{3}$. The concentration of heavy metal ions, acidity, alkalinity and $\mathrm{pH}$ of the medium were also controlled in the samples. The reactions that occurred during the desorption of metals can be described by:

$$
\begin{gathered}
\mathrm{R}_{2} \mathrm{Cu}+\mathrm{H}_{2} \mathrm{SO}_{4} \leftrightarrow 2 \mathrm{RH}+\mathrm{CuSO}_{4} \\
\mathrm{R}_{2} \mathrm{Zn}+\mathrm{H}_{2} \mathrm{SO}_{4} \leftrightarrow 2 \mathrm{RH}+\mathrm{ZnSO}_{4}
\end{gathered}
$$

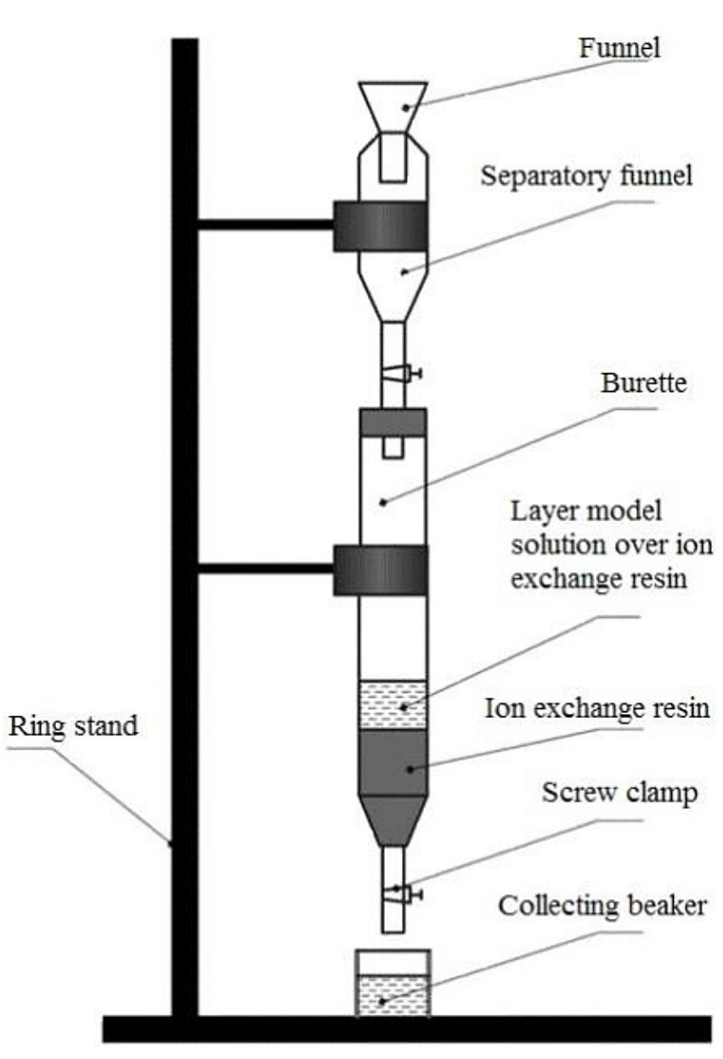

Figure 1. Column for ion exchange water treatment 


$$
\mathrm{R}_{2} \mathrm{Ni}+\mathrm{H}_{2} \mathrm{SO}_{4} \leftrightarrow 2 \mathrm{RH}+\mathrm{NiSO}_{4}
$$

The desorption degree was calculated as the ratio of the mass of the desorbed and sorbed metal ions by means of the formula, $\%$ :

$$
Z=\sum_{i=1}^{n} \frac{m_{i . \text { desorb. }}}{m_{\text {sorb. }}} \cdot 100
$$

where: $m_{\text {i.desorb. }}, m_{\text {sorb. }}$ are the number of the desorbed metal ions from the i-th sample of the regeneration solution and the sorbed ions on the ionite, $\mathrm{meq} / \mathrm{dm}^{3}$.

\section{RESULTS AND DISCUSSION}

It is known that strong-acid KU-2-8 cation exchanger has a high capacity for heavy metal cations and resistance to both acidic and alkaline media, has regenerative properties, which allow the exchanger to be used numerously [Olshanova et al. 1970].

The results of the sorption of copper, zinc and nickel ions from model copper and zinc sulfate solutions and copper and nickel sulfate solutions at the cation exchanger resin under dynamic conditions are represented in fig. 2, 3, and 4.

During the research (Fig. 2), the capacity of ionite reaches about $2050 \mathrm{meq} / \mathrm{dm}^{3}$ in the passage of $0.01 \mathrm{n}$ solutions and the sorption of metals has almost the same selectivity for separately measured concentrations. The acidity of the solutions decreased and the $\mathrm{pH}$ increased, as the cation exchanger was depleted. Before the breakthrough of the heavy metal ions in the analyzed solution, $3 \mathrm{dm}^{3}$ of the model solutions were passed, and before full saturation of the ionite, it was necessary to pass about $4.5-4.75 \mathrm{dm}^{3}$.
The sorption of $\mathrm{Cu}^{2+}-\mathrm{Zn}^{2+}$ and $\mathrm{Cu}^{2+}-\mathrm{Ni}^{2+}$ from 0.02 and $0.05 \mathrm{n}$ sulfate solutions of copper and zinc, copper and nickel is shown in Fig. 3 and in Fig. 4. The graphs show that the acidity decreased along with the ionite capacity. The breakdown of the copper, zinc and nickel ions occurs only after passing $1.5 \mathrm{dm}^{3}$ (Fig. 3) and $0.5 \mathrm{dm}^{3}$ of the model solutions (Fig. 4). The complete saturation of KU-2-8 cation exchanger took place after passing $3 \mathrm{dm}^{3}$ (Fig. 3) and $1.4 \mathrm{dm}^{3}$ (Fig. 4) of the model solutions.

The results demonstrate that the capacity of ionite increases slightly along with the concentration of metals in the solutions. In general, the sorption of the mixture of metals (copper and zinc, copper and nickel) was quite effective.

While comparing the results of other scientists [Homelia et al. 2017; Malin et al. 2016] who carried out sorption and desorption of metal ions on KU-2-8 cation exchanger in the $\mathrm{H}^{+}$- and $\mathrm{Na}^{+}-$ forms, we can say that the ion exchange process occurs quite effectively both from dilute solutions and from the concentrated model solutions containing heavy metal ions.

In order to evaluate the efficiency of ion-exchange water treatment from heavy metals, it is necessary to take into account not only the sorption capacity, but also the degree of regenerating cation exchangers. Therefore, after studying the sorption of heavy metals on the cation exchanger, regeneration by sulfuric acid was conducted.

The results of the regeneration of the ion exchanger in the $\mathrm{Cu}^{2+}-\mathrm{Zn}^{2+}$ and $\mathrm{Cu}^{2+}-\mathrm{Ni}^{2+}-$ forms are shown in Fig. 5, 6 and 7. The regeneration of the ion exchanger by 5,8 and $10 \%$ sulfuric acid was quite effective. The concentration of heavy metal ions during the regeneration decreased from about $600 \mathrm{meq} / \mathrm{dm}^{3}$ to $0.1 \mathrm{meq} / \mathrm{dm}^{3}$, and the acidity increased from about $300 \mathrm{meq} / \mathrm{dm}^{3}$ to $1000 \mathrm{meq} / \mathrm{dm}^{3}$ (Fig. 5).

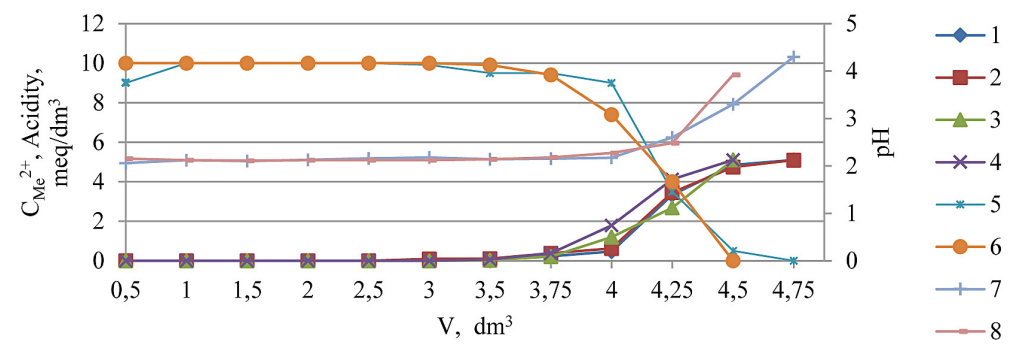

Figure 2. Dependence of the initial concentration of copper (1), zinc (2) ions:

$\left[\mathrm{Cu}^{2+}\right]=5.1 \mathrm{meq} / \mathrm{dm}^{3},\left[\mathrm{Zn}^{2+}\right]=5.1 \mathrm{meq} / \mathrm{dm}^{3}$, acidity (5) and $\mathrm{pH}(7)$; copper (3), nickel (4) ions:

$\left[\mathrm{Cu}^{2+}\right]=5.1 \mathrm{meq} / \mathrm{dm}^{3},\left[\mathrm{Ni}^{2+}\right]=5.1 \mathrm{meq} / \mathrm{dm}^{3}$, acidity $(6)$ and $\mathrm{pH}(8)$ from the model solutions by filtering the volume through the KU-2-8 in the $\mathrm{H}^{+}$-form $\left(\mathrm{V}_{\mathrm{i}}=20 \mathrm{~cm}^{3}\right)\left(\mathrm{TEDC}(1)=1034 \mathrm{meq} / \mathrm{dm}^{3}\right.$, TEDC (2) $=1027.5 \mathrm{meq} / \mathrm{dm}^{3}$, TEDC (3) $=1030 \mathrm{meq} / \mathrm{dm}^{3}$, TEDC (4) $\left.=1005 \mathrm{meq} / \mathrm{dm}^{3}\right)$ 


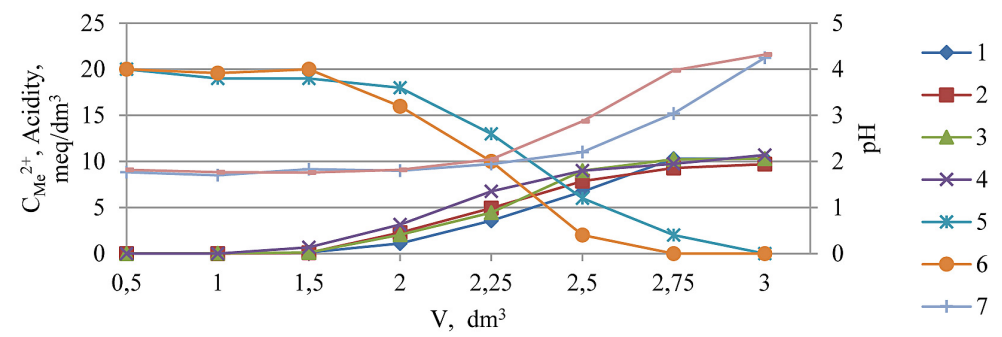

Figure 3. Dependence of the initial concentration of copper (1), zinc (2) ions: $\left[\mathrm{Cu}^{2+}\right]=10.3 \mathrm{meq} / \mathrm{dm}^{3}$, $\left[\mathrm{Zn}^{2+}\right]=9.7 \mathrm{meq} / \mathrm{dm}^{3}$, acidity (5) and pH (7); copper (3), nickel (4) ions: $\left[\mathrm{Cu}^{2+}\right]=10.3 \mathrm{meq} / \mathrm{dm}^{3}$, $\left[\mathrm{Ni}^{2+}\right]=10.7 \mathrm{meq} / \mathrm{dm}^{3}$, acidity (6) and $\mathrm{pH}(8)$ from the model solutions by filtering the volume through the KU-2-8 in the $\mathrm{H}^{+}$-form $\left(\mathrm{V}_{\mathrm{i}}=20 \mathrm{~cm}^{3}\right)\left(\right.$ TEDC $(1)=1128 \mathrm{meq} / \mathrm{dm}^{3}$, TEDC (2) $=998 \mathrm{meq} / \mathrm{dm}^{3}$, $\operatorname{TEDC}(3)=1064.7 \mathrm{meq} / \mathrm{dm}^{3}$, TEDC $\left.(4)=1056.8 \mathrm{meq} / \mathrm{dm}^{3}\right)$

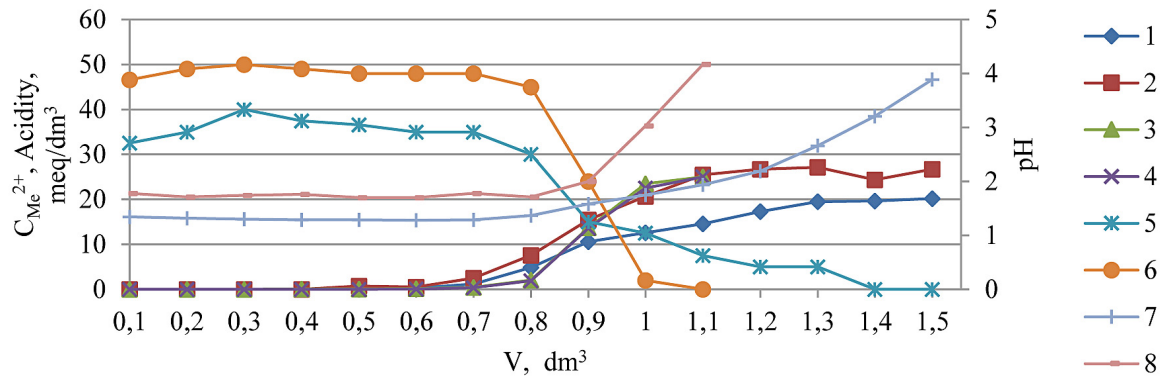

Figure 4. Dependence of the initial concentration of copper (1), zinc (2) ions: $\left[\mathrm{Cu}^{2+}\right]=20.4 \mathrm{meq} / \mathrm{dm}^{3}$, $\left[\mathrm{Zn}^{2+}\right]=27.6 \mathrm{meq} / \mathrm{dm}^{3}$, acidity (5) and $\mathrm{pH}(7)$; copper (3), nickel (4) ions: $\left[\mathrm{Cu}^{2+}\right]=25 \mathrm{meq} / \mathrm{dm}^{3}$, $\left[\mathrm{Ni}^{2+}\right]=25 \mathrm{meq} / \mathrm{dm}^{3}$, acidity (6) and $\mathrm{pH}(8)$ from the model solutions by filtering the volume through the KU-2-8 in the $\mathrm{H}^{+}$-form $\left(\mathrm{V}_{\mathrm{i}}=20 \mathrm{~cm}^{3}\right)\left(\right.$ TEDC $(1)=926.42 \mathrm{meq} / \mathrm{dm}^{3}$, TEDC (2) $=1181.2 \mathrm{meq} / \mathrm{dm}^{3}$, $\left.\operatorname{TEDC}(3)=1050.5 \mathrm{meq} / \mathrm{dm}^{3}, \operatorname{TEDC}(4)=1057.5 \mathrm{meq} / \mathrm{dm}^{3}\right)$

During the ionite regeneration by $8 \% \mathrm{H}_{2} \mathrm{SO}_{4}$, the concentration of the $\mathrm{Cu}^{2+}-\mathrm{Zn}^{2+}$ and $\mathrm{Cu}^{2+}-\mathrm{Ni}^{2+}$ ions decreased from $800 \mathrm{meq} / \mathrm{dm}^{3}$ to $0.01 \mathrm{meq} / \mathrm{dm}^{3}$. The acidity increased to $1560-1620 \mathrm{meq} / \mathrm{dm}^{3}$ (Fig. 6) respectively.

Complete ionite regeneration was achieved by using $10 \%$ sulfuric acid (Fig. 7) when $400-440 \mathrm{~cm}^{3}$ of acid has passed. The concentration of metals decreased from about 835 to $0 \mathrm{meq} / \mathrm{dm}^{3}$ and the acidity increased from 600 to $2000 \mathrm{meq} / \mathrm{dm}^{3}$.

In general, with the use of 5, 8 and $10 \%$ sulfuric acid, the degree of heavy metals desorption from the cationite was at $96 \ldots 100 \%$. Regeneration was most effective at the ratio of the passed volume of $10 \% \mathrm{H}_{2} \mathrm{SO}_{4}$ acid. The metal mixer extraction on the cation exchanger showed that the metals are being removed not worse than during sorption and desorption of one type of cations.

After obtaining the regenerative solutions of metal mixtures, it is advisable to carry out electrolysis of these solutions, which is the next step in treatment of the wastewater contaminated with heavy metal ions. Thus, it is possible to realize a non-waste process of metal extraction during the ion exchange from water [Koliehova et al. 2018].

\section{CONCLUSIONS}

The sorption processes of heavy metal mixtures (copper-zinc, copper-nickel) on strong-acid $\mathrm{KU}-2-8$ cation exchanger in the $\mathrm{H}^{+}$-form were studied. It was determined that the sorption of the two metals mixture on the cation exchanger is effective and the selectivity of this cation exchanger is almost identical to these metals.

The desorption results of the metal mixtures by means of 5,8 and $10 \%$ sulfuric acid on KU-2-8 cation exchanger in the $\mathrm{Cu}^{2+}, \mathrm{Zn}^{2+}$ and $\mathrm{Ni}^{2+}$-forms are showed that the regeneration is almost $100 \%$.

It was established that after the sorption and desorption of the heavy metals on the cation exchanger, it is expedient to conduct electrolysis of these metals, which will enable the creation of closed systems for treatment of the wastewater contaminated by heavy metals. 


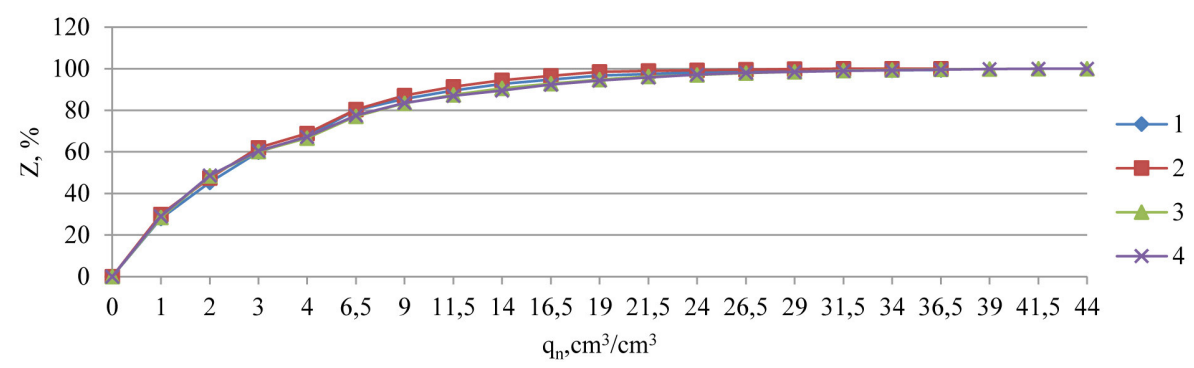

Figure 5. Dependence of the degree of copper (1) and zinc (2), copper (3) and nickel (4) ions desorption from the KU-2-8 in the $\mathrm{Cu}^{2+}-\mathrm{Zn}^{2+}$ and $\mathrm{Cu}^{2+}-\mathrm{Ni}^{2+}$-forms $\left(\mathrm{V}_{\mathrm{i}}=20 \mathrm{~cm}^{3}\right)$ on the specific consumption of $5 \%$ $\mathrm{H}_{2} \mathrm{SO}_{4}$ solution $\left(\mathrm{cm}^{3} / \mathrm{cm}^{3}\right)$ at a mass of the sorbed ions, meq $/ \mathrm{dm}^{3}: 20.6(1), 20.5(2), 21.01$ (3) and 21.15 (4)

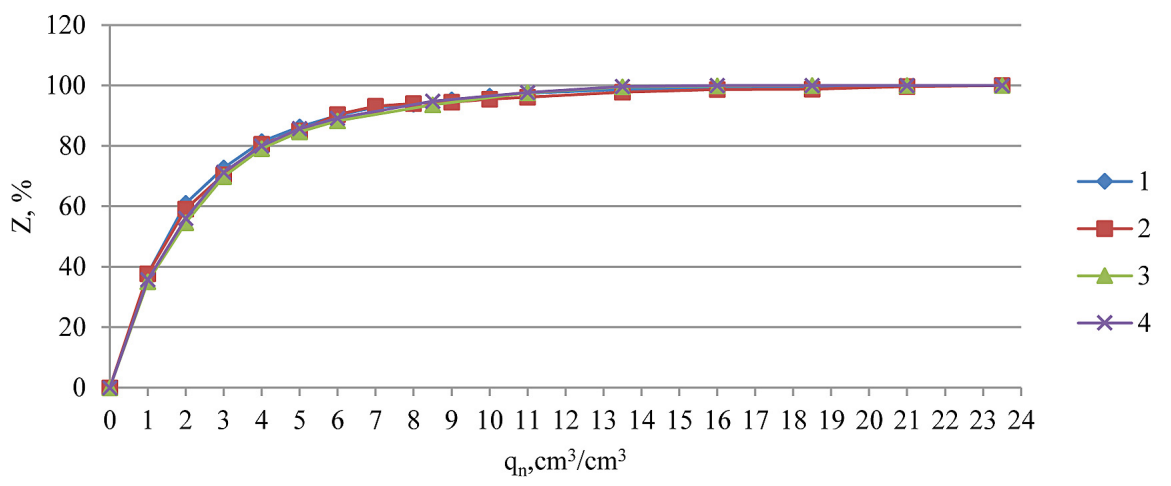

Figure 6. Dependence of the degree of copper (1) and zinc (2), copper (3) and nickel (4) ions desorption from the KU-2-8 in the $\mathrm{Cu}^{2+}-\mathrm{Zn}^{2+}$ and $\mathrm{Cu}^{2+}-\mathrm{Ni}^{2+}$-forms $\left(\mathrm{V}_{\mathrm{i}}=20 \mathrm{~cm}^{3}\right)$ on the specific consumption of $8 \% \mathrm{H}_{2} \mathrm{SO}_{4}$ solution $\left(\mathrm{cm}^{3} / \mathrm{cm}^{3}\right)$ at a mass of the sorbed ions, meq/ $/ \mathrm{dm}^{3}: 22.56(1), 19.96(2), 20.63(3)$ and 20.7 (4)

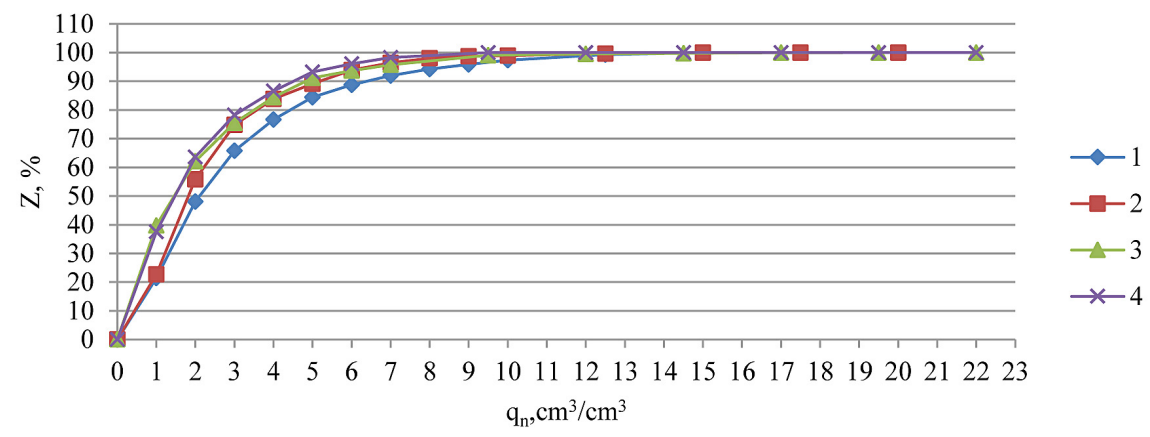

Figure 7. Dependence of the degree of copper (1) and zinc (2), copper (3) and nickel (4) ions desorption from the KU-2-8 in the $\mathrm{Cu}^{2+}-\mathrm{Zn}^{2+}$ and $\mathrm{Cu}^{2+}-\mathrm{Ni}^{2+}$ forms $\left(\mathrm{V}_{\mathrm{i}}=20 \mathrm{~cm}^{3}\right)$ on the specific consumption of $10 \%$ $\mathrm{H}_{2} \mathrm{SO}_{4}$ solution $\left(\mathrm{cm}^{3} / \mathrm{cm}^{3}\right)$ at a mass of the sorbed ions, meq $/ \mathrm{dm}^{3}: 18.53$ (1), 23.6 (2), 21.3 (3) and 21.14 (4)

\section{REFERENCES}

1. Azimi A., Azari A., Rezakazemi M., Ansarpour M. 2017. Removal of Heavy Metals from Industrial Wastewaters: A Review. ChemBioEng, 4 (1), 37-59.

2. Carstea E.M., Bridgeman J., Baker A., Reynolds D.M. 2016. Fluorescence spectroscopy for wastewater monitoring: A review. Water Res., 95, 205-219.

3. Dolina L.F. 2008. Sovremennaya tekhnika i tekhnologii dlya ochistki stochnykh vod ot soley tyazhelykh metallov: monografiya. Kontinent, Dnepropetrovsk. (in Russian)
4. Femina Carolin C., Senthil Kumar P., Saravanan A., Janet Joshiba G., Naushad Mu. 2017. Efficient Techniques for the Removal of Toxic Heavy Metals from Aquatic Environment: A Review. Journal of Environmental Chemical Engineering, 5 (3), 2782-2799.

5. Gunatilake S.K. 2015. Methods of Removing Heavy Metals from Industrial Wastewater. Journal of Multidisciplinary Engineering Science Studies, 1 (1), 12-18.

6. Homelia M.D., Trokhymenko H.H., Hlushko O.V. 2017. Vplyv ioniv zhorstkosti ta vzaiemnyi vplyv ioniv vazhkykh metaliv na efektyvnist yikh sorbtsii 
na kationiti. Problemy vodopostachannia, vodovidvedennia ta hidravliky, 28, 104-112. (in Ukrainian)

7. Koliehova A.S., Trokhymenko H.H., Homelia M.D. 2018. Vyvchennia ionoobminnykh protsesiv vyluchennia ioniv midi ta tsynku na kationiti KU-2-8 ta elektrokhimichne rozdilennia reheneratsiinykh rozchyniv u systemi $\mathrm{Cu}-\mathrm{Zn}$. Vcheni zapysky Tavriiskoho natsionalnoho universytetu imeni V. I. Vernadskoho. Seriia: Tekhnichni nauky,T. 29(68), № 1(2), 142-147. (in Ukrainian)

8. Lure Y. 1989. Spravochnik po analiticheskoy khimii. Khimiya Publ., Moskva. (in Russian)

9. Malin V. P., Homelia M.D., Halimova V.M. 2016. Efektyvnist zastosuvannia kationitu KU-2-8 pry vyluchenni ioniv midi $\mathrm{z}$ vody $\mathrm{v}$ prysutnosti ioniv zhorstkosti. Problemy vodopostachannia, vodovidvedennia ta hidravliky. 26, 45-55. (in Ukrainian)

10. Malovanyy M., Sakalova H., Vasylinych T., Kryklyvyi R. 2019. The Research of Ammonium Concentrations in City Stocks and Further Sedimentation of Ion-Exchange Concentrate. Journal of Ecological Engineering, 20(1), 158-164.
11. Markov V.F., Ikanina Ye.V., Maskaeva L.N. 2010. Issledovanie ionoobmennykh svoystv kompozitsionnogo sorbenta na osnove kationita KU-2×8 i gidroksida zheleza (III) po otnosheniyu k ionam medi (II). Sorbtsionnye i khromatograficheskie protsessy, 10 (6), 830-839. (in Russian)

12. Olshanova K.M., Potapova M.A., Morozova N.M. 1970. Praktikum po khromatograficheskomu analizu. Uchebnoe posobie dlya studentov nekhimicheskikh spetsialnostey vuzov. Vysshaya shkola, Moskva. (in Russian)

13. Pawan K.B. 2012. Heavy Metals in Environment. Lambert Academic Publishing, Germany.

14. Trokhymenko G. Gomelya M. 2017. Development of low waste technology of water purification from copper ions. Chemistry \& Chemical Technology, 11 (3), 372-377.

15. Verbych S., Hilal N., Sorokin G., Leaper M. 2005. Ion Exchange Extraction of Heavy Metal Ions from Wastewater. Separation Science and Technology, 39 (9), 2031-2040. 